The University of Maine

DigitalCommons@UMaine

English Faculty Scholarship

English

4-1-1992

\title{
Rockabye Lady: Pregnancy as Punishment in Popular Culture
}

Deborah Rogers

University of Maine - Main, deborah.rogers@umit.maine.edu

Follow this and additional works at: https://digitalcommons.library.umaine.edu/eng_facpub

Part of the English Language and Literature Commons

\section{Repository Citation}

Rogers, Deborah, "Rockabye Lady: Pregnancy as Punishment in Popular Culture" (1992). English Faculty Scholarship. 8.

https://digitalcommons.library.umaine.edu/eng_facpub/8

This Article is brought to you for free and open access by DigitalCommons@UMaine. It has been accepted for inclusion in English Faculty Scholarship by an authorized administrator of DigitalCommons@UMaine. For more information, please contact um.library.technical.services@maine.edu. 


\title{
Rockabye Lady: Pregnancy as Punishment in Popular Culture
}

\author{
DEBORAH D. ROGERS
}

Childbearing is double-edged. Not only does Western culture enshrine motherhood as women's destiny, it also devalues pregnancy as ploy, punishment, illness, and, as it is categorized by most American insurance companies, disability. So tenacious is this double message that it was first articulated in popular culture in the early novel and persists in today's American soap operas. In both genres pregnancy is endorsed, even as the subtext reflects women's anxieties and fears about pain and mortality, calling into question the happiness women are supposed to experience in a condition that is surrounded by the rhetoric of punishment and subordination.

The ideological basis of this contradiction is deep-rooted in Western culture. In the Bible, if pregnancy functions as a woman's greatest reward, it also becomes her supreme punishment, all in the service of male domination. Although the Biblical injunction is, "Be fruitful and multiply," this same source considers the pain of parturition as a special punishment meted out for female sexuality. Used to justify male dominance, this duality was introduced in popular culture over 250 years ago in the novel, a form that, like the soap opera, is addressed to an audience comprised mostly of women. Samuel Richardson's Pamela, widely considered to be the first English novel, a genre that is, to my mind, the direct antecedent of soap operas, cites Biblical authority for these notions. ${ }^{1}$ In Pamela pregnancy is valorized, albeit negatively, in terms of "how uneasy many women are, not to be in this circumstance (my good Lady Davers particularly, at times), and Rachel and Hannah in holy writ; and how a childless estate might lessen one in the esteem of one's husband." ${ }^{2}$ Yet even as pregnancy is privileged, the agony of childbirth is interpreted as punishment for female sexuality. In Pamela's paraphrase the whole serves as a pretext for female subordination:

the apostle... says, That be suffers not a woman to teach, nor to usurp autbority over the man, but to be in silence. - And what is the reason he gives? Why a reason that is a natural consequence of the curse on the first disobedience, that she shall be in subjection to her husband. - For, says he, Adam was NOT deceived; but the woman, being deceived, was in the transgression. As much as to say, "had it not been for the woman, Adam had kept his

Deborah D. Rogers is Associate Professor of English, University of Maine, Orono, Maine 04469-0122, U.S.A.

${ }^{1}$ Pamela's position as the first English novel has recently been challenged, especially by feminist critics, who argue for a female tradition predating Richardson. Even if Pamela is not the first novel, it is still a seminal text.

${ }^{2}$ Samuel Richardson, Pamela or Virtue Rewarded, 4 vols., in The Complete Novels of Mr. Samuel Richardson, introduced by Austin Dobson and William Lyon Phelps (1 $1740^{-4} \mathrm{I}$; rept. London: William Heinemann, 1902), 3, 282. 
integrity, and therefore her punishment shall be, as it is said, I will greatly multiply thy sorrow in thy conception: in sorrow shalt thou bring forth children, - and thy busband shall rule over thee. But, nevertheless, if thou shalt not survive the sharpness of thy sorrow, thy death shall be deemed to be ... an alleviation of thy part of the entailed transgression .... ${ }^{3}$

These cultural pieties, which dictate that a woman's natural role is one of suffering and subordination, bear repeating: the doctrine of Original Sin, which brings sex and death into the world, stipulates that the woman never "usurp authority over the man, but ... be in silence ... in subjection to her husband .... " It also connects this male dominance to female pain at delivery, defining both causally as punishment for female sexuality: woman's "punishment shall be... in sorrow shalt thou bring forth children, - and thy busband shall rule over thee."

Perhaps nowhere are these sentiments perpetuated more emphatically than on American daytime soap operas, which simultaneously valorize and deprecate pregnancy. Soaps regularly characterize having a baby as "what life is all about," as "the single most important thing in a woman's life." According to soap ideology, "Women who have little ones are the luckiest people in the world...." Procreation is viewed as women's most important function. Consider, for example, the way one representative soap character observed the transforming effects of her positive pregnancy test: "Look at me... I'm a different woman today, a fulfilled woman, as I've never been before. I found out something this morning - the most wonderful news of my life.... I'm pregnant." 6

At the same time that pregnancy is idealized, it is devalued, continuing the long tradition of reading pregnancy as punishment for female sexuality. For example, on The Young and the Restless one unwed mother experiences life-threatening complications in childbirth. For weeks she is in a coma, suspended precariously between life and death. On the same soap an adulterous affair results in pregnancy, and, in short order, abortion, and institutionalization. (Note that abortion is read literally as insanity.)

The punitive notion of pregnancy, where unmarried pregnant women are standard tropes for sexual transgression, is not confined to The Young and the Restless but is pervasive on the soaps. Especially telling is the situation of Pine Valley's resident femme fatale and self-styled feminist, the much-married Erica Kane Brent Martin Chandler Cudahy on Ail My Children. Immediately after she denounces the institution of marriage, declaring her "liberation" from having "fallen into the cultural trap of thinking I needed marriage to be happy," Erica receives a call from her physician, who informs her that she is expecting. Some months later Erica is hospitalized, in danger of losing both her baby and her life. At this point she explicitly connects previous moral lapses with her current danger: "My baby - I'm losing my baby .... This is my punishment." Convinced that she and her baby are dying, and as she puts it, now "paying the price," Erica reflects, "God is punishing me... That's why I'm hooked up to all these machines." (This equation of female sexuality and death, which is elaborated in

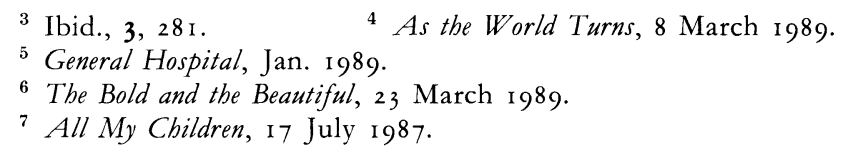


the Richardsonian novel, reaches its extreme form in the recent depiction of AIDS on the soaps: the three soap operas with AIDS plots all feature patients who are women with no history of drug abuse! Endorsing conservative sexual behavior by punishing female promiscuity, the soaps project onto women a disease that in America is - according to statistics from the Centers for Disease Control in Atlanta - primarily confined to homosexual and bisexual males and to intravenous drug addicts. $)^{8}$

Identified with moral failure, an unmarried pregnant woman becomes a social text in which sexuality is made visible. Married women hardly fare better on the soaps, where establishing paternity often presents major problems. Pregnancy is, of course, a particularly appropriate punishment since the "crime" or causality is unambiguous. It is possible to impose all these metaphoric equivalences on pregnancy because personal aspects of women's lives simply show more than men's and are therefore more open to public scrutiny. Although in the case of pregnancy, this has a biological foundation, it is difficult to see why sexual asymmetry extends in this way to such public tokens of private relationship as engagement rings or the title "Mrs." which have no male equivalent.

Reinforcing the notion that female sexuality is punished by pregnancy, which may be fatal - or, at the very least, excruciating - the soaps help perpetuate a double bind for women in real life: bearing children and continuing a male line are enshrined as women's greatest achievement, even as exercising their sexuality is punished by the pain of pregnancy and domination. To "hook" and keep a man, women are supposed to be sexually alluring, but realizing female sexuality, even within a monogamous relationship, may lead to pregnancy and pain. Physiologically vulnerable during gestation and labor, pregnant women are additionally subjected to ideological confusion that enforces female subordination.

Surely we should re-examine such views, especially as they find expression in our ideas about childbirth, which seems to be accompanied by much pain that is simply gratuitous. Not only do some American obstetricians limit their practices to natural childbirth, permitting women no choice; many women prefer to accept pain during delivery or are inadequately informed about alternatives such as epidural anesthesia. But so deeply are our views about parturition inscribed in popular culture, that the issue may be one of ideology as much as medical necessity, which may serve to perpetuate female punishment and subordination. This is all the more likely, considering the stories we have been telling ourselves in Scripture and in popular culture. Here pregnancy is a vehicle for our profoundly ambivalent attitude towards female sexuality, which not only causes pain but also justifies the "ideal" Western family structure in which males dominate.

${ }^{8}$ Deborah D. Rogers, "AIDS Spreads to the Soaps," New York Times, 28 Aug. 1988, $\mathrm{H}_{29}$. 